\title{
HISTORIC NEST RECORDS OF THE PEREGRINE FALCON IN SOUTHERN SASKATCHEWAN AND SOUTHERN MANITOBA
}

MARC J. BECHARD, Department of Biology, University of La Verne, La Verne, California. 91750

The historic breeding range of the Peregrine Falcon east of the Rocky Mountains extended north through much of Montana and Alberta. ${ }^{35} 11$ There is only presumptive evidence that peregrines once occupied suitable sites along Hudson Bay near Churchill, ${ }^{2}{ }^{7}$ but otherwise range descriptions have not included Saskatchewan and Manitoba. This note provides evidence for nest sites in the southern portions of both provinces, extending the historic breeding range.

Thompson in 1891 described the peregrine as an occasional summer resident near Winnipeg, and listed migration records for Portage la Prairie, Carberry and Two .Rivers in Manitoba, and from Cote's Reserve in what is now Saskatchewan. ${ }^{12}$ Similarly, Mitchell in 1924 knew of only one peregrine specimen from Saskatchewan, obtained at Old Wives Lake on 2 May 1922, but knew of no evidence of nesting within the province. ${ }^{8}$

Recent studies indicate that the Peregrine Falcon no longer breeds in Saskatchewan or Manitoba. ${ }^{2}{ }^{3}$ Godfrey, ${ }^{4}$ Houston and Street, ${ }^{6}$ and Nero, ${ }^{910}$ all failed to find any evidence of peregrine nests in the Cypress Hills, Saskatchewan River, Lake Athabasca, or northeastern regions of Saskatchewan, although occasional cliff ledges are available in all of these areas. Jehl and Smith $^{7}$ knew of no documented nesting sites for the Churchill area of Manitoba, but reported a courting pair near Cape Merry as late as 1957.

While searching the egg collection of the Western Foundation of Vertebrate Zoology, Los Angeles, California, for historic records of raptor nest sites, I discovered two previously unpublished records of the Peregrine Falcon from southern Manitoba and southern Saskatchewan, prior to the 1920's. O. G. Turner, Jr., collected two eggs on 20 May 1887 from a nest situated $13.3 \mathrm{~m}$ above ground on the ledge of a small cliff near Gladstone, Manitoba. J.E. Bowman made a collecting trip on 6 May 1916 to Battle Creek in the Cypress Hills of extreme southwestern Saskatchewan, where he found a nest with four eggs on the shelf of a $13 \mathrm{~m}$ cliff, approximately $1.2 \mathrm{~m}$ from the top. Since Prairie Falcons still nest on cliff ledges in the Cypress Hills, although not known to do so in Manitoba, nest site information was not sufficient to confirm the validity of the collectors' identifications. Egg size could not be used for identification since eggs of Peregrine Falcons are similar to those of Prairie Falcons.' The dark red color of both sets I am reporting, however, is typical of Peregrine Falcons, so I judge the identifications to be valid in each instance.

The two nests reported herein are apparently the only documented nests from southern Manitoba and the entire province of Saskatchewan. They indicate that at the time of initia 
settlement, the Peregrine Falcon was at least a rare breeding resident of southern Manitoba and southern Saskatchewan.

\section{Acknowledgements}

I would like to thank C. S. Houston for suggesting this study. Thanks are also extended to Lloyd $\mathrm{F}$. Kiff for use of the records of the Western Foundation of Vertebrate Zoology.

'BENT, A. C. 1937. Life histories of North American birds of prey. Part I. Smithsonian Inst., U.S. Nat. Mus. Bull. 167.

${ }^{2} \mathrm{CADE}, \mathrm{T}$. J. and R. W. FYFE. 1970. The North American peregrine survey, 1970. Can. Field-Nat. 84:231-245.

${ }^{3}$ FYFE, R. W., TEMPLE, S. A., and T.J. CADE. 1976. The 1975 North American Peregrine Falcon survey. Can. FieldNat. 90:228-273.

4GODFREY, W. E. 1950. Birds of the Cypress Hills and Flotten Lake Regions, Saskatchewan. Ottawa: Nat. Mus. Canada Bull. 120.

${ }^{5}$ HICKEY, J. J. 1969. Peregrine Falcon populations. Milwaukee: Univ. Wisconsin Press.

HOUSTON, C. S. and M. G. STREET. 1959. The birds of the Saskatchewan River, Carlton to Cumberland. Regina: Sask. Nat. Hist. Soc., Spec. Publ. 2.

JEHL, J. R. Jr. and B. A. SMITH. 1970. Birds of the Churchill Region, Manitoba. Winnipeg: Manitoba Mus. of Man \& Nature, Spec. Publ. 1.

MITCHELL, H. H. 1924. Birds of Saskatchewan. Can. Field-Nat. 38:101-118.

NERO, R. W. 1963. Birds of the Lake Athabasca region, Saskatchewan. Regina: Sask. Nat. Hist. Soc., Spec. Publ. 5.

NERO, R.W. The birds of northeastern Saskatchewan. Regina: Sask. Nat. Hist. Soc., Spec. Publ. 6.

SNOW, C. 1972. Habitat management for endangered species. American Peregrine Falcon (Falco peregrinus anatum) and Arctic Peregrine Falcon (Falco peregrinus tundrius).
Washington: Bureau of Land Management, U.S. Dept. of Interior, Report 1.

${ }^{12}$ THOMPSON, E. E. 1891. The birds of Manitoba. Proc. U.S. Nat. Museum 13:457-643.

\section{A BREEDING RECORD FOR ORCHARD ORIOLES IN SASKATCHEWAN}

BRENDA DALE, 3629 18th Avenue, Regina, Saskatchewan. S4S OC1

The first Saskatchewan record of breeding Orchard Orioles was a pair at Fort San in 1971.' Several pairs of Orchard Orioles were seen in Saskatchewan in 1980. Gollop ${ }^{2}$ reported pairs near Moose Jaw and Oxbow. Shadick and Luterbach ${ }^{3}$ documented nests and young for Orchard Orioles at Buffalo Pound Lake and Saskatoon. All the 1980 males were in first year plumage.

On 15 June 1981 a pair of Orchard Orioles was seen at the north end of Last Mountain Lake (111/2 miles east of Simpson). The male was in mature plumage. On subsequent visits the male was heard singing (20 June), the female was seen sitting on a nest $4-5 \mathrm{~m}$ above the ground (25,June) and the pair was seen feeding 3 young in the nest (18-22 July). By 23 July the young were out of the nest. Two of the young were seen on 25 July.

'CALLIN, E. M. 1975. First records of the Orchard Oriole in Saskatchewan. Blue Jay 33:176-177.

${ }^{2}$ GOLLOP, J. B. 1980. Prairie Provinces Region. Am.Birds 34:905-906.

${ }^{3}$ SHADICK, S. J. and BOB LUTERBACH. 1980. Saskatchewan breeding records for Red Crossbill, Orchard Oriole and Red-headed Woodpecker. Blue Jay 38:247-249. 